\title{
Digital Archeology Is Here (and Has Been for a While)
}

\author{
Andre Costopoulos* \\ McGill University, Montreal, QC, Canada \\ Keywords: archeology, opinion, history of archeology, digital archeology, computers in archeology, computational \\ archeology
}

Archaeology is now fully in a period of experimenting with the computer and gradually adopting it as one of its major tools for research (Whallon, 1972; p. 29).

[The volume] is an examination of how approaches to archaeology, both methodological and theoretical, need to intelligently utilize the world of Information and Communication Technology and how this can redefine the potential of archaeology in the twenty-first century (Evans and Daly, 2006; p. 4).

The creation of a large databank is to begin soon (Whallon, 1972; p. 41).

I want to stop talking about digital archeology. I want to continue doing archeology digitally. This is what Frontiers in Digital Archaeology is about. I echo (Morgan and Eve, 2012; p. 523) the statement that "we are all digital archaeologists." This statement wants to be radical but is in fact a mundane recognition of a state of normality that has existed for at least 20 years and has described a significant segment of the archeological community for at least 40 years.

Evidence of the reality of digital archeology is all around us in the discipline's data collection and curation (Roosevelt et al., 2015), analysis [mainly through GIS, see Conolly and Lake (2006)],

OPEN ACCESS

Edited by:

Ben Marwick,

University of Washington, USA

Reviewed by:

Enrico R. Crema,

Universitat Pompeu Fabra, Spain

*Correspondence:

Andre Costopoulos andre.costopoulos@mcgill.ca

Specialty section:

This article was submitted to Digital Archaeology, a section of the journal Frontiers in Digital Humanities

Received: 08 January 2015 Accepted: 29 February 2016

Published: 16 March 2016

Citation:

Costopoulos A (2016) Digital Archeology Is Here (and Has Been for a While).

Front. Digit. Humanit. 3:4. doi: 10.3389/fdigh.2016.00004 visualization [work in and elaborating on Stanco et al. (2011), among others], public outreach and participation (Richardson, 2013), and training methods. The reflection on what it means to be a digital archeologist is ongoing [Evans and Daly (2006) and work that builds on it]. Perhaps, the best evidence is the growing prominence of archeology blogs in driving the dissemination and interpretation of results (see Colleen Morgan's middlesavagery or John Hawks' weblog for notable examples in very different regions of the discipline).

In this first editorial, I would like to lay the groundwork for the journal as a place primarily to do archeology digitally, rather than as a place to discuss digital archeology. In the social sciences and humanities, we have an unfortunate tendency to make approaches and tools into objects of study (literally, we essentialize them) and to organize the conversation around them.

There are meaningful and even heavy conversations about the implications in other fields of the use of new digital tools. We will have those conversations in this journal. But those conversations in other fields have tended to facilitate rather than impede the setting up of things, such as Genbank ${ }^{1}$ and arXiv. $^{2}$ Those conversations have been immensely productive, but they have been more focused and results oriented than I feel they have been so far in archeology. I must admit that I am a bit embarrassed at the public expense involved in the numerous rather sterile meetings in which I have participated about the digital turn in archeology and the setting up of public archives, community GIS, etc., for what so far I consider very little result. The carbon footprint of some of these meetings must have been stupendous. All the right people were at the table (I mean that sincerely), all the right things were said, all the right anxieties were aired out, and all the right authorities were cited. But I do not think the expense so far has been justified by the outcomes.

\footnotetext{
${ }^{1}$ http://www.ncbi.nlm.nih.gov/genbank/

${ }^{2}$ http://arxiv.org/
} 
That is not to say that nothing has been happening, and in fact there has been very significant progress in the digitization of archeology. But the progress has often been quite removed from the conversations about digital archeology. This is not surprising. As inveterate early adopters, archeologists have been increasingly digital in practice if not in word as long as computers and interactive media have been available. I have always found a certain poetic symmetry in the fact that archeologists, who are concerned with understanding past technology and social systems, have consistently sought to harness emerging and even imagine future technology to do so. One of our prominent intellectual forebears, for example, apparently made no distinction between the reconstruction of social organization on the basis of excavated pasts or imagined futures. As Francis Carsac, he envisioned future societies around an imagined technology in his science fiction novels. As François Bordes, he created Paleolithic societies on the basis of excavated remains of technology.

This characteristic of archeologists allows Bewley (2003) to talk about the first century of aerial archeology on the 100th anniversary of the first heavier than air powered flight. This is also why Harvard's Earnest Hooton, initially trained as an archeologist, as early as the mid-1930s and before digital computers were available, was using "a species of electric sorting, counting, and tabulating machine, which swallows cards with holes punched in them and spews up figures and statistical tables" (Hooton quoted in Eames, 1990; p. 110). Nor did Brues (1954), one of his students, has to wait for a digital computer to invent the use of simulation for the study of human evolution. Even before archeologists invented "analog computer archeology" in the first half of the twentieth century, they were at the forefront of the development and application of innovative survey and mapping techniques and of field photography in the nineteenth century.

Not surprisingly then, archeologists have been at the bleeding edge of new media and communications technology. Starting in the 1870s, Oscar Montelius developed the first true "continental scale" archeology network by the early and aggressive use of railway, steamer, and other emerging fast means of communication and transportation (Trigger, 1989; p. 157). He used newly available, better, and cheaper means of publication and distribution to bring his colleagues masses of detailed archeological drawings and diagrams. I am sure Montelius would have been a monster blogger.

My own generation rapidly embraced new tools, such as digital photography and field data capture on laptops and GPS units. In the early 1990s, we improvised proto GIS models of sites and regions in Hypercard and spreadsheet software (Okkonen, 1997; Banninig, 1991; Smith, 1995). We used C to roll our own agent-based simulations before SWARM and NetLogo were available (Lake, 2000). We used the storage potential of CDs and the new hypertextual capabilities of the web to enhance our dissertations, resulting in a variety of rather formative experiences [see Holtorf (2004) for a discussion]. Encouragingly, our students are busy replicating the pattern and leaving us behind as technological dinosaurs. Dragged along by them, we are now adapting to blogs as means of rapid dissemination of data and analysis and integrating social media into the accelerating archeological conversation, leading me to paraphrase Dorothy: Toto, I have a feeling we are not in Usenet anymore.

The opportunities for democratization of the discipline and engagement of avocational archeologists and communities are unprecedented in their scale, but not new in themselves. It is no secret to boreal archeologists, for example, that the regions we study are immense and our numbers are few. Most of our "discoveries" come from local partners. The fact that they can now tweet us pictures of semi-subterranean house floors from the middle of the woods or post their latest interpretive speculations on Facebook instead of waiting to tell us about them next summer does not change what they do or their importance as partners. It merely changes for the better the extent to which we can all work together.

Archeological reconstruction in the physical world has always been an important tool for archeologists and an even more important way for the public to engage with the past and participate in the archeological imagination. The expansion of archeological reconstruction into virtual spaces in the 1990s (Reilly, 1990; Barcelo et al., 2000) has made it possible for anyone with modest computer equipment and an Internet connection to be in an imagined past, to manipulate it, and to help create it. Much of the online reconstruction of the past and the bulk of online debate about how to accurately represent past contexts has escaped the orbit of professional archeology and been captured by the computer gaming community. One need only look at the often informed and sophisticated debates taking place about realism on forums dedicated to historically based computer games to see that the full range of archeological concerns, from the details of material culture to economic and social organization, are explored by a globally distributed community that dwarfs professional archeology by several orders of magnitude.

Different projects, such as the Digital Archaeological Record ${ }^{3}$ and the Archaeology Data Service, ${ }^{4}$ are seeking to archive and make widely available archeological data in ways that Montelius could only dream of, but about which he would certainly have been excited. They are allowing rapid and novel synthesis of data to test hypotheses in ways the original creators of the data had not envisioned [for instance, Collard et al. (2010)].

These quite bold attempts at making the best use of our available technological resources keep bringing up serious problems of standardization, intellectual property, funding, ethics, and so on. These problems are not new. They are not unique to digital archeology or even characteristic of it. They belong to archeology as a whole. Some will gradually be solved, and some will remain, as they have, since the dawn of the discipline. Let us not get hypnotized by their current ephemeral incarnation. Let us treat them as the timeless things they are and focus on their essence.

Forget the label. We are building a digital archeology by doing archeology digitally. This is what we do.

\section{AUTHOR CONTRIBUTIONS}

The author confirms being the sole contributor of this work and approved it for publication.

\section{ACKNOWLEDGMENTS}

The author thanks the reviewers and editors for their helpful comments.

\footnotetext{
${ }^{3}$ http://www.tdar.org/

${ }^{4}$ http://archaeologydataservice.ac.uk/
} 


\section{REFERENCES}

Banninig, E.B. (1991). The Wadi Ziqlab HyperCard project. Society for American Archaeology Bulletin 9: 8-9.

Barcelo, J.A., Forte, M., and Sanders, D.H. (2000). Virtual Reality in Archaeology. Oxford: ArcheoPress BAR 843.

Bewley, R.H. (2003). Aerial archaeology. The first century. In Aerial Photography and Archaeology 2003 a Century of Information, Archaeological Reports, Vol. 4, Edited by J. Bourgeois and M. Meganck, 15-30. Ghent: Ghent University.

Brues, A.M. (1954). Selection and polymorphism in the A-B-O blood groups. American Journal of Physical Anthropology 12: 559-98. doi:10.1002/ ajpa. 1330120408

Collard, M., Edinborough, K., Shennan, S., and Thomas, M.G. (2010). Radiocarbon evidence that migrants introduced farming to Britain. Journal of Archaeological Science 37: 866-70. doi:10.1016/j.jas.2009.11.016

Conolly, J., and Lake, M.W. (2006). Geographical Information Systems in Archaeology. Cambridge: Cambridge University Press.

Eames, C. (1990). A Computer Perspective: Background to the Computer Age. Boston: The President and Fellows of Harvard College.

Evans, T.L., and Daly, P.T. (2006). Digital Archaeology: Bridging Method and Theory. London: Routledge.

Holtorf, C. (2004). The future of electronic scholarship. In Internet Archaeology 15. Available at: http://intarch.ac.uk/journal/issue15/11/index.html

Lake, M.W. (2000). MAGICAL computer simulation of mesolithic foraging. In Dynamics in Human and Primate Societies: Agent-Based Modeling of Social and Spatial Processes, Edited by G.J. Gumerman and T.A. Kohler, 107-143. New York: Oxford University Press.

Morgan, C., and Eve, S. (2012). DIY and digital archaeology: what are you doing to participate? World Archaeology 44: 521-37. doi:10.1080/00438243.2012.741810
Okkonen, J. (1997). Personal communication.

Reilly, P. (1990). Towards a virtual archaeology. In Computer Applications in Archaeology, Edited by K. Lockyear and S. Rahtz, 133-139. Oxford: BAR 565.

Richardson, L. (2013). A digital public archaeology? In Papers from the Institute of Archaeology. London: UCL.

Roosevelt, C.H., Cobb, P., Moss, E., Olson, B.R., and Unlusoy, S. (2015). Excavation is digitization: advances in archaeological practice. Journal of Field Archaeology 40: 325-46. doi:10.1179/2042458215Y.0000000004

Smith, N. (1995). Towards a study of ancient Greek landscapes: the Perseus GIS In Archaeology and Geographical Information Systems, Edited by G. Lock and Z. Stancic, 239-248. London: Taylor Francis.

Stanco, F., Baltiato, S., and Gallo, G. (2011). Digital Imaging for Cultural Heritage Preservation. Boca Raton: CRC Press, Taylor Francis.

Trigger, B.G. (1989). A History of Archaeological Thought. Cambridge University Press.

Whallon, R. (1972). The computer in archaeology: a critical survey. Computers in the Humanities 7: 29-45. doi:10.1007/BF02403759

Conflict of Interest Statement: The author declares that the research was conducted in the absence of any commercial or financial relationships that could be construed as a potential conflict of interest.

Copyright (C) 2016 Costopoulos. This is an open-access article distributed under the terms of the Creative Commons Attribution License (CC BY). The use, distribution or reproduction in other forums is permitted, provided the original author(s) or licensor are credited and that the original publication in this journal is cited, in accordance with accepted academic practice. No use, distribution or reproduction is permitted which does not comply with these terms. 